\title{
ANALISIS SISTEM AKUNTANSI PEMBERIAN KREDIT (Studi Kasus pada Koperasi Simpan Pinjam Arta Makmur Blitar)
}

\author{
Endah Masrunik \\ Puji Andayani \\ Dosen Fakultas Ekonomi Universitas Islam Balitar Blitar \\ e-mail:endahmasrunik@gmail.com
}

\begin{abstract}
ABSTRAK
Sistem informasi akuntansi merupakan salah satu cara yang dapat digunakan oleh manajemen dalam melakukan pengawasan terhadap beberapa fungsi yang menjadi bawahannya. Sehingga sistem informasi akuntansi menjadi sumber daya yang harus dikelola dengan tepat agar terjadi sistem yang terpadu dan terintegrasi dalam menyediakan informasi kepada pemakai untuk pengambilan suatu keputusan bisnis yang tepat. Tujuan dari penelitian ini adalah untuk mengetahui sistem akuntansi pemberian kredit yang telah digunakan oleh Koperasi Simpan Pinjam Tunas Arta Makmur Blitar. Metode yang digunakan dalam penelitian ini yaitu metode penelitian kualitatif dengan pendekatan studi kasus. Hasil penelitian ini menunjukkan bahwa Koperasi Simpan Pijam Arta Makmur dalam pemberian kredit sudah melaksanakan sistem akuntansi yang tepat, namun masih ada salah satu fungsi yang merangkap tugas kerja, yaitu fungsi marketing. Dimana fungsi marketing selain mencari nasabah juga bertugas untuk melaksanakan survey. Sehingga ke obyektifan dari hasil survey ini masih diragukan. Selain itu survey tidak dilaksanakan dengan tepat. Dan ketika peminjam telah melunasi pinjamanya biasanya langsung diberikan pinjaman berikutnya tanpa melalui prosedur pemberian kredit yang sesuai. Sehingga hal ini rentan sekali pada terjadinya kredit bermasalah.
\end{abstract}

\section{Kata kuci: Sistem Informasi Akuntansi, Penelitian Kualitatif, Kredit}

\section{PENDAHULUAN}

Sistem informasi akuntansi merupakan hal yang sangat penting yang dibutuhkan oleh manajemen serta pemakai lainnya. Dengan sistem informasi akuntansi yang baik akan dapat mengahasilkan informasi akuntansi yang akurat dan bermanfaat bagi pemaakainya. Dalam upaya mencapai tujuannya suatu entitas atau organisasi harus mampu mengelola sistem akuntansinya yang berkaitan dengan segala macam kegiatan dari entitas tersebut. sistem akuntansi merupakan organisasi formulir, catatan, dan laporan yang dikoordinasikan sedemikian rupa untuk menyediakan informasi keuangan yang dibutuhkan oleh menejemen guna memudahkan pengelolaan perusahaan (Mulyadi, 2005:3). Sedangkan menurut krismiaji (2002:4) sistem akuntansi adalah sistem yang memproses data dan transaksi guna menghasilkan informasi yang bermanfaat untuk merencanakan, mengendalikan, dan mengoperasikan bisnis.

Koperasi juga merupakan suatu entitas yang penting, yang membutuhkan informasi akuntansi. Untuk mampu berperan sebagai badan usaha yang tangguh dan mandiri koperasi harus mampu mengelola kegiatan dan aktivitasnya dengan 
baik. Menurut Undang-Undang Nomor 25 tahun1992 "koperasi adalah badan usaha yang beranggotakan dengan melandaskan kegiatannya berdasarkan prinsip koperasi sebagai gerakan ekonomi rakyat yang berdasarkan atas azas kekeluargaan".anoraga dan widiyanti (2007:19) adapun jenis-jenis koperasi didasarkan pada kebutuhan dan efisiensi dalam ekonomi yaitu: Koperasi Konsumsi, Koperasi Produksi, Koperasi Jasa, Koperasi Serba Usaha(KSU), dan Koperasi Simpan Pinjam atau koperasi kredit.

Koperasi simpan pinjam merupakan koperasi yang bergerak dalam bidang pemupukan simpanan dari para anggotanya, untuk kemudian dipinjamkan kembali kepada para anggotanya yang memerlukan tambahan modal. Dalam pemberian pinjaman koperasi harus mampu memberikan prosedur yang mudah dipahami oleh para anggotanya. Pada sistem akuntansi terdapat perencanaan informasi akuntansi yang dibutuhkan oleh manajemen dan pemakai lainnya, serta perancangan sistem pengelolaan informasi untuk menghasilkan informasi akuntansi.Sistem informasi akuntansi yang baik mampu menghasilkan informasi yang bermanfaat.

Koperasi Simpan Pinjam Tunas Arta Makmur didirikan untuk membantu dan mendorong pertumbuhan perekonomian dan pembangunan daerah disegala bidang. Sebagai badan usaha yang usahanya di bidang jasa keuangan Koperasi Simpan Pinjam Tunas Arta Makmur berupaya memberikan pelayanan yang terbaik kepada nasabahnya dengan menyediakan berbagai macam simpanan dan pemberian kredit. Pemberian kredit merupakan usaha dari Koperasi Tunas Arta Makmur yang paling pokok, maka dari itu koperasi perlu memberikan informasiinformasi yang akurat dan mudah dalam hal persyaratan mengajukan kredit pinjaman serta prosedur-prosedur yang memudahkan pemohon kredit dalam mengurus pinjaman kreditnya. Selain itu pemisahan fungsi-fungsi juga harus menjadi hal yang utama bagi sebuah entitas. Sehingga dalam melaksanakan tugas dan kewajibannya dapat diketahui bagaimana pelaksanaannya. Dan dengan pemisahan fungsi yang jelas akan memudahan entitas dalam mengendalikan atau mengontrol semua kegiatan dan aktivitas dari entitas tersebut. Agar kegiatan perkreditan berjalan dengan lancar Koperasi Simpan Pinjam Tunas Arta Makmur memerlukan sistem akuntansi pemberian kredit untuk mengetahui prosedur pemberian kredit dan pengelolaan uang yang sesuai prosedur. Dalam hal ini sistem akuntansi pemberian kredit perlu diteliti untuk mengetahui apakah prosedur pemberian kredit, dokumen yang digunakan, fungsi yang terkait dan catatan akuntansi sudah berjalan dengan baik dan sesuai dengan prosedur agar tidak terjadi resiko kredit. Agar kredit yang diberikan debitur akan kembali pada bank dengan lancar sesuai perjanjian kredit. Jadi sistem akuntansi pemberian kredit mempunyai peranan yang sangat penting bagi perkembangan sektor pemberian kredit pada koperasi.

\section{Rumusan Masalah}

Berdasarkan latar belakang yang diuraikan diatas, maka masalah penelitian yang dapat dirumuskan sebagai berikut: bagaimana sistem pemberian kredit yang diterapkan pada Koperasi Simpan Pinjam Tunas Arta Makmur blitar? 


\section{Tujuan Penelitian}

Berdasarkan latar belakang dan rumusan masalah yang telah dikemukakan maka tujuan dari penelitian adalah untuk mengetahui sistem akuntansi yang diterapkan dalam pemberian kredit pada Koperasi Tunas Arta Makmur.

\section{Batasan Masalah}

Batasan masalah dalam penelitian ini sangat diperlukan untuk memperjelas permasalahan yang dibahas dan sebagai upaya untuk menghindari adanya salah tafsir dan perbedaan pengertian. Maka dengan melihat judul penulis membatasi masalah dalam penelitian ini berkisar pada sistem akuntansi pemberian kredit pada Koperasi Simpan Pinjam Tunas Arta Makmur blitar.

\section{Sistem dan Prosedur}

Sistem adalah suatu kerangka dari prosedur-prosedur yang saling berhubungan dan disusun sesuai dengan skema yang menyeluruh untuk melaksanakan suatu kegiatan atau fungsi utama dari perusahaan (Baridwan, 2009:3). Sistem diciptakan untuk mengenai sesuatu yang berulangkali atau secara rutin terjadi (Mulyadi, 2005:2). Sistem terdiri dari jaringan prosedur, prosedur merupakan suatu urutan kegiatan kritikal, biasanya melibatkan beberapa orang dalam satu departemen atau lebih, yang dibuat untuk menjamin penanganan secara seragam transaksi perusahaan yang terjadi berulang-ulang (Mulyadi, 2005:4).

Dari beberapa pengertian sistem diatas dapat disimpulkan bahwa sistem informasi akuntansi merupakan organisasi formulir, catatan, prosedur dan alat yang terjadi secara berulang yang digunakan untuk mengelola data-data akuntansi agar menghasilkan informasi-informasi yang dibutuhkan oleh manajemen guna melaksanakan pengendalian intern maupun pihak-pihak yang berkepentingan. Sehingga dari tujuan sistem tersebut maka dibutuhkan karakteristik-karakterstik sistem agar dapat mencapai tujuan tersebut, diantaranya yaitu (Mulyanto, 2009:2):1). Component sytem, 2). Boundary,3). Environment,4). Interface, 5). Input, 6). Processing, 7). Outputdan 8). Feedback. Dengan berbagai karakteristik sistem tersebut diatas, diharapkan suatu organisasi atau entitas dapat menerapkan suatu pngedalian itern yang baik sehingga tujuan dari entitas tersebut dapat tercapai. Selain itu juga terdapat beberapa unsur dari sistem informasi akuntansi yang memerlukan pengawasan serta pengendalian yang baik, agar semua system dapat berjalan sesuai dengan prosedur yang ditetapkan. Barry E. cushing yang diterjemahkan oleh kosasih ( 2007:23) mengemukakan unsur-unsur system informasi akuntansi yaitu:

1. Sumber daya manusia

Sumber daya manusia yang digunakan dalam suatu perusahaan untuk mengolah data akuntansi adalah karyawan yang mempunyai pengetahuan dan pengalaman yang cukup dibidangnya, artinya karyawan itu mempunyai keahlian dan ketrampilan dalam menunjang suatu system infromasi akuntansi yang ada diperusahaan.

2. Alat 
Alat dapat berupa benda atau mesin yang membantu sumber daya manusia dalam aktivitasnya menghasilkan suatu informasi, jenis alat yang sering digunakan adalah computer dan mesin tik.

3. Catatan

Data dihasilkan dari catatan berupa jurnal-jurnal, buku besar dan buku tambahan data juga dihasilkan dari formulir-formulir yang digunakan sebagai bukti tertulis dari transaksi.

4. Laporan

Hasil akhir dari system informasi akuntansi adalah informasi akuntansi keuangan dan informasi akuntansi manajemen.

5. Formulir

Formulir merupakan unsur pokok dalam system informasi akuntansi yang dapat digunakan untuk mencatat transaksi sehingga merupakan bukti tertulis.

6. Prosedur

Prosedur merupakan gambaran yang mencakup sejumlah jalannya kegiatan mulai dari saat dimulainya kativitas sampai pada saat berakhirnya aktivitas tersebut, sehingga dengan adanya prosedur diharapkan dapat terlaksananya pekerjaan dengan efektif, efisien dan ekonomis.

Sistem informasi akuntansi memuat informasi-informasi yang penting yang digunakan dalam pengambilan keputusan. Sehingga sistem informasi memerlukan pengembangan yang berkelanjutan agar tidak terjadi tumpang tindih tugas dan tanggungjawab antar berbagai fungsi. Selain itu juga akan lebih memudahkan dalam perencanaan, pengendalian dan evaluasi serta perbaikan dalam entitas tersebut. Baik dari sisi aktivitas atau kegiatan juga dalam data-data yang diperunakan serta tugas dan tanggungjawab setiap fungsi yang terkait. Adapun tujuan dari pengembangan system akuntansi (Mulyadi, 2016:15):

1. Untuk menyediakan informasi bagi pengelolaan kegiatan usaha baru.

2. Untuk memperbaiki informasi yang dihasilkan oleh system yang sudah ada, baik mengenai mutu, ketepatan penyajian, maupun struktur informasinya.

3. Untuk memperbaiki pengendalian akuntansi dan pengecekan intern, yaitu untuk memperbaiki tingkat keandalan (realibility) informasi akuntansi dan menyediakan catatan lengkap mengenai pertanggungjawaban dan perlindungan kekayaan perusahaan.

4. Untuk mengurangi biaya klerikal dalam penyelenggaraan catatan akuntansi.

\section{Koperasi}

Menurut Undang-Undang Nomor 12 tahun1967 tentang pokok-pokok perkoperasian di dalam pasal 3 dikemukakan mengenai pengertian koperasi, yaitu Koperasi Indonesia adalah organisasi ekonomi rakyat yang berwatak social, beranggotakan orang-orang atau badan-badan hukum koperasi yang merupakan tata susunan ekonomi rakyat sebagai usaha bersama berdasarkan atas asas kekeluargaan. Sedangkan menurut muldjono (2016:1), koperasi adalah badan usaha yang beranggotakan orang-orang atau badan hukum. Sehingga dari beberapa definisi diatas terdapat 4 unsur yang menunjukkan ciri khusus koperasi sebagai suatu bentuk organisasi (Partomo, S Titik, 2009:13): 1). Adanya sejumlah individu yang bersatu dalam kelompok yang memiliki sekurang-kurangnya satu 
kepentingan. 2). Angan-angan individual dari kelompok koperasi antara lai bertekad mewujudkan tujuannya untuk memperbaiki situasi ekonomi dan social mereka melalui usaha-usaha bersama dan saling memantu (swadaya dari kelompok koperasi). 3). Sebagai suatu instrument (sarana) untuk mencapai tujuan itu, yaitu melalui pmbentukan suatu perusahaan. 4). Adanya sasaran dari perusahaan koperasi ini, yaitu melaksanakan kegiatan-kegiatan yang menunjang atau memperbaiki situasi ekonomi para anggota ( memperbaiki situasi ekonomi perusahaan atau rumah tangga anggota)

Jenis kegiatan koperasi berdasarkan kegiatan usaha koperasi diantaranya yaitu (muljono, 2012: 4); 1).Koperasi konsumen; Koperasi konsumsi merupakan koperasi yang usahanya memenuhi kebutuhan sehari-hari anggota koperasi. 2). Koperasi Produsen; Koperasi produksi yaitu kperasi yang anggotanya menghasilkan produk yang kemudian dijual atau dipasarkan melalui koperasi. 3) Koperasi Simpan Pinjam; koperasi yang melayani kegiatan peminjaman dan penyimpanan uang kepada para anggota.Koperasi harus mampu memberikan maanfaat kepada setiap anggotanya. Adapun manfaat koperasi simpan pinjam diantaranya: a). memberi kemudahan anggota untuk memperoleh modal usaha, b). memberi keuntungan kepada anggota melalui Sisa Hasil Usaha, c). mengembangkan usaha anggota koperasi, d). meniadakan praktek rentenir (Muljono, 2012:5).

\section{Kredit}

Kredit merupakan kemampuan untuk melakukan pembelian atau suatu pinjaman dengan suatu janji pembayarannya akan dilakukan, ditangguhkan pada suatu angka waktu yang disepakati ( Sastradipuera, 2004:15). Sedangkan menurut Suhardjono (2003:11) kredit adalah penyediaan uang atau yang disamakan dengan itu berdasarkan persetujuan pinjam meminjam antara bank dengan lain pihak dalam hal mana pihak peminjam berkewajiban melunasi hutangnya setelah jangka waktu tertentu dengan jumlah bunga yang telah ditentukan.

Adapun fungsi kredit secara luas di antaranya(muldjono, 2007):

a. Untuk meningkatkan daya guna uang

b. Untuk meningkatkan peredaran dan lalu lintas uang

c. Untuk meningkatkan daya guna barang

d. Meningkatkan peredaran barang

e. Sebagai alat stabilitas ekonomi

f. Untuk meningkatkan pemerataan pendapatan

g. Untuk meningkatkan hubungan internasional

Tujuan dari pemberian kredit mempunyai tujuan tertentu yang tidak terlepas dari misi suatu lembaga keuangan. Adapun tujuan pemberian kredit di antaranya:

1. Mencari keuntungan

2. Membantu usaha nasabah

3. Membantu pemerintah

Pemberian kredit kepada pihak lain oleh suatu lembaga perkreditan didasarkan atas kepercayaan. Dengan demikian kredit merupakan penberian kepercayaan kepada pihak lain (debitur). Menurut Kasmir 
(2002:94) kredit mengandung unsur-unsur sebagai berikut : A) Kepercayaan ; Kepercayaan merupakan suatu keyakinan bagi si pemberi kredit bahwa kredit yang diberikan (baik berupa barang, uang atau jasa) benar-benar diterima kembali di masa yang akan datang sesuai jangka waktu kredit. Kepercayaan diberikan oleh bank sebagai dasar utama yang melandasi mengapa suatu kredit berani di kucurkan. Oleh karena itu sebelum kredit dikucurkan harus dilakukan penelitian dan penyelidikan lebih dulu secara mendalam tentang kondisi nasabah, baik secara intern maupun ekstern. Penelitian dan penyelidikan tentang kondisi pemohon kredit sekarang dan masa lalu, untuk menilai kesungguhan dan etikat baik nasabah terhadap bank. B). Kesepakatan ; Kesepakatan ini dituangkan dalam suatu perjanjian dimana masing-masing pihak menandatangani hak dan kewajibannya. Kemudian dituangkan dalam akad kredit dan ditandatangani kedua belah pihak sebelum kredit dikucurkan.C) Jangka Waktu; Setiap kredit yang diberikan memiliki jangka waktu tertentu, jangka waktu ini mencakup masa pengembalian kredit yang telah disepakati. Jangka waktu tersebut bisa berbentuk jangka pendek, jangka menengah atau jangka panjang. D). Resiko; Adanya suatu tenggang waktu pengembalian akan menyebabkan suatu resiko tidak tertagihnya atau macet pemberian kredit. Semakin panjang suatu kredit semakin besar resiko nya demikian pula sebalikya. Resiko ini menjadi tanggungan bank, baik resiko yang disengaja oleh nasabah yang lalai, maupun oleh resiko tidak sengaja. Misalnya terjadi bencana alam atau bangkrutnya usaha nasabah tanpa ada unsur kesengajaan lainnya. E). Balas jasa ; Merupakan keuntungan atas pemberian suatu kredit atau jasa tersebut yang kita kenal dengan bunga. Balas jasa dalam bentuk bunga dan biaya administrasi kedit merupakan keuntungan bank. Sedangkan bagi bank yang berdasarkan prinsip syariah balas jasanya ditentukan dengan bagi hasil.

Prinsip-prinsip pemberian kredit ( firdaus, 2001:39) diantaranya yaitu: 1. Character (watak / kepribadian), yaitu bank harus yakin bahwa calon peminjam termasuk orang yang berwatak baik dan dibuktikan dengan tingkah laku yang baik, selalu memegang teguh dan sebagainya. 2. Capacity (kemampuan) yaitu bank harus yakin bahwa calon peminjam mampu menjalankan usahanya dengan baik atau mampu mendapatkan uang untuk sumber pelunasan utangnya. 3 . Capital (modal) yaitu bank harus mengetahui beberapa banyak modal yang telah dimiliki oleh calon peminjam, sehingga tidak seluruhnya mengandalkan pinjaman dari bank. 4. Condition of Economy (kondisi ekonomi) yaitu bank harus yakin bahwa kondisi ekonomi akan menunjang sekurang-kurangnya tidak menghambat kelancaran usaha yang akan dijalankan oleh calon peminjam.5.Collateral(jaminan atau agunan) yaitu jaminan atau agunan apa yang dapat diberikan calon peminjam untuk tambahan pengamanan bagi bank atau kredit yang akan dilepas. Selanjutnya terhadap 5C of kredit diatas bisa ditambahkan, yaitu : 6. Covering (insursnce covering) yaitu penutupan asuransi atas kredit yang diberikan oleh bank tersebut atau penutupan asuransi atas barang-barang jaminan yang digunakan oleh debitur dan coverage yaitu jaminan yang diasuransikan. 


\section{METODE PENELITIAN}

Metode penelitian merupakan cara ilmiah untuk mendapatkan data dengan tujuan dan kegunaan tertentu (sugiyono, 2016:2), data yang diperoleh dari penelitian dapat digunakan untuk memahami, memecahkan da mengantisipasi masalah . Untuk dapat mencapai suatu tujuan tersebut peneliti harus mengumpulkan data-data, yang diperlukan sebagai bahan penelitian dan selanjutnya diolah guna menarik suatu gagasan dan dijadikan sebagai kesimpulan akhir.

Penelitian ini dilakukan untuk mengetahui atau menggali informasi lebih dalam terkait dengan sistem akuntansi pemberian kredit pada Koperasi Simpan Pinjam Tunas Arta.Metode penelitian yang digunakan dalam penelitian ini adalah metode penelitian kualitatif diskriptif dengan pendekatan studi kasus.Dimana peneliti menganalisis dan menggambarkan kasus-kasus atau masalah-masalah yang terjadi dalam sebuah entitas hasil dari penelitian yang dilakukan.

Penelitian kualitatif merupakan prosedur penelitian yang menghasilkan data diskriptif berupa kata-kata tertulis atau lisan dari orang-orang dan prilaku yang dapat diamati (Moleong, 2005:4). Basrowi dan sudikin (2002:2) penelitian kualitatif bertujuan untuk mendapatkan pemahaman tentang kenyataan melalui proses berfikir induktif. Metode observasi diskriptif dimana peneliti melakukan penjelajahan umum, dan menyeluruh, melakukan diskripsi terhadap semua yang dilihat, didengar dan dirasakan (Sugiyono, 2014:230). Sehingga metode kualitatif ini merupakan cara yang dilakukan untuk menghasilkan data yang dapat diukur secara numerik yang berisi pemahaman tentang kenyataan melalui proses berfikir dari dalam yang disajikan menggunakan kata-kata tertulis atau lisan dari orangorang dan prilaku yang diteliti.

Teknik pengumpulan data juga sangat penting dalam melakukan penelitian, agar data yang diambil atau diperoleh tepat dan sesuai dengan apa yang diharapkan. Teknik pengumpulan data yang digunakan peneiti dalam penelitian ini diantaranya adalah:

1. Wawancara; wawancara merupakan proses percakapan dengan maksud untuk mengontruksi mengenai orang, kejadian, kegiatan, organisasi, motivasi, perasaan dan sebagainya yang dilakukan oleh dua pihak yakni pewawancara yang mengajukan pertanyaan dengan orang yang diwawancarai (Bungin, 2012:155). Dalam penelitian ini yang menjadi informan adalah bagian pengawas Koperai Simpan Pijam Tunas Arta.

2. Dokumentasi: dilakukan dengan mengumpulkan, mencatat dan juga memanfaatkan data-data yang berkaitan dengan penelitian di lapangan. Dengan dokumentasi nantinya diharapkan dapat mendukung hasil penelitian dari wawancara yang telah dilakukan sebelumnya.

3. Studi kepustakaan; metode pengumpulan data yang diarahkan kepada pencarian data informasi melalui dokumen, baik tertulis, foto, gambar tau data elektronik yang dapat mendukung proses penelitian.

\section{PEMBAHASAN}

Sistem informasi akuntansi merupakan salah satu cara yang digunakan untuk pengendalian intern dalam sebuah entitas bisnis, dengan adanya sistem 
informasi akuntansi yang memadai maka kegiatan operasi entitas akan lebih efisien dan efektif. Sehingga menghasikan informasi yang handal dan dapat dipercaya.

Koperasi Simpan PInjam Tunas Arta Makmur didirikan berdasarkan surat keputusan no 33/18/BH/1409.104.104/X/2004 pada tanggal 7 oktober 2004 ber alamat atau ber tempat kedudukan di jalan manukwari kelurahan satreaan kecamatan kanigoro kabupaten Blitar. Koperasi Simpan PInjam Tunas Arta Makmur memiliki 1 kantor pusat dan 2 kantor kas yaitu berada di jalan raya patok desa sidorejo kecamatan ponggok kabupaten Blitar dan di jalan raya Trisula desa lorejo kecamatan bakung kabupaten Blitar. Sistem informasi akuntansi sangat diperlukan dalam sebuah entitas. Tanpa sistem informasi akuntansi yang jelas, maka suatu entitas akan kesulitan dalam mengontrol aktivitas-aktivitas yang terjadi dalam usahanya. Begitupun dengan Koperasi Simpan Pinjam Arta Makmur, telah menerapkan sistem akuntansi dalam setiap aktivitas dikoperasinya.Termasuk dalam hal pemberian kredit.Karena kredit merupakan hal yang paling utama dalam kegiatan koperasi simpan pinjam.

Sistem akuntansi pemberian kredit pada Koperasi Simpan Pinjam Tunas Arta Makmur memilik beberapa fungsi yang terkait, diantaranya yaitu: Fungsi kasir, Fungsi marketing, Fungsi akuntansi. Fungsi-fungsi tersebut diatas saling bekerja sama dalam melakukan pelayanan nasabahnya untuk pemberian kredit. Fungsi kasir bertugas memeriksa kelengkapan berkas pemohon kredit serta menyiapkan slip bukti penerimaan pinjaman beserta uang. Fungsi marketing bertugas memeriksa kelengkapan persyaratan permohonan kreddit dan melakukan survey kepada pemohon kredit.Sehingga fungsi marketing ini selain mencari nasabah atau calon pemohon kredit juga melakukan tugas menyurve calon pemohon kredit.Sedangkan fungsi akuntansi bertugas mencatat data peminjam kedalam buku daftar jaminan, mencata data peminjam ke dalam buku register, mencata data peminjam ke dalam buku SWP, mencatat data peminjam ke dalam buku rekapitulasi.

Selain fungsi-fungsi yang terkait diatas, terdapat beberapa dokumen yang digunakan dalam pemberian kredit di Koperasi Simpan Pinjamm Tunas Arta. Dokumen merupakan secarik kertas yang digunakan untuk merekam terjadinya transaksi yang pertama kalinya sebagai dasar pencatatan dalam catatan (Mulyadi, 2005:3). Adapun dokumen-dokumen yang digunakan dalam sistem informasi akuntansi pemberian kredit pada Koperasi Tunas Arta Makmur ialah dokumen permohonan kredit ( Foto Copy KTP, Foto copy KK, Foto copy BPKP atau Surat Tanah, Foto copy STNk), formulir permohonan kredit; formulir ini disediakan oleh koperasi dan diisi leh pemohon kredit. Formulir ini berisi tentang identitas calon peminjam secara lengkap, jumlah pijaman, keterangan usaha dan jenis agunan yang digunakan sebagai jaminan untuk memperoleh pinjaman dan dilampirkan dokumen syarat. Formulir calon anggota; formulir ini diisi oleh bagian akuntansi yang berisi identitas lengkap pemohon pinjaman serta besarnya simpanan-simpanan yang harus dbayar oleh pemohon pinjaman. Formulir surat penyerahan dan kuasa menjual; berisi identitas pemohon serta penyerahan agunan dan pemberian kuasa untuk menjual agunan bila terjadi adanya kreedit bermasalah. Formulir tanda terima titipan dan pernyataan: sebagai bukti bahwa 
telah menerima barang agunan dari pemohon pinjaman. Kartu anggota merupakan sebuah kartu sebagai tanda bahwa pemohon telah menjadi anggota koperasi Simpan Pinjam Tunas Arta dan berisi identitas pemohon. Slip tanda penerimaan jaminan, slip bukti penerimaan jaminan, slip penyetoran, kwitansi peminjaman. Selain itu, di Koprasi Simpan Pinjam Tunas Arta juga memiliki beberapa jaringan prosedur yang membentuk sistem, yaitu:1). Prosedur Permohonan Kredit. 2). Prosedur uji kelayakan dan persetujuan kredit. 3). Prosedur pencairan kredit. Catatan akuntansi yang digunakan yang digunakan dalam Koperasi Simpan Pinjam Tunas Arta yaitu jurnal umum yang digunakan untuk mencatat transaksi yang tidak dicatat dalam jurnal khusus, jurnal pengeluaran kas yang digunakan untuk mencatat jumlah kredit yang diberikan kepada pemohon kredit, jurnal penerimaan kas digunakan untuk mencatat besarnya angsuran kredit, buku besar digunakan untuk merekap semua bukti pengeluaran dan penerimaan kas yang terjadi di koperasi.

Berikut merupakan sistem pemberian kredit di Koperasi Simpan Pinjam Tunas Arta Makmur:

1. Pemohon kredit menyiapkan dokumen permohonan kredit (foto kopy KTP, foto Kopy $\mathrm{KK}$, foto kopy BPKB, fotokopy STNK), mengisi formulir permohonan kredit yang selanjutnya diserahkan ke bagian kasir beserta dokumen-dokumen permohonan kredit.

2. Bagian kasir menerima formulir permohonan kredit beserta dokumendokumen permohonan kredit dari pemohon kredit, untuk selanjutnya diperiksa kelengkapan dokumennya dan menyerahkan dokumen permohonan kredit tersebut kepada marketing untuk dilakukan survey.

3. Bagian marketing menerima kelengkapan dokumen-dokumen permohonan kredit tersebut dari kasir, untuk kemudian dilakukan survey dan analisis terhadap barang jaminan yang digunakan pemohon kredit untuk mengajukan kredit dan mengenal karakter dari pemohon kredit melalui kerabat dan tetangga pemohon.

4. Berdasarkan survey dan analisis tersebut, kemudian marketing mengambil keputusan untuk menerima atau menolak permohonan kredit tersebut.

5. Apabila permohonan kredit ditolak, maka marketing membuatkan surat pemberitahuan yang untuk selanjutnya diserahkan kepada pemohon kredit beserta kelengkapan dokumen permohonan kredit yang lain.

6. Apabila permohonan kredit diterima, maka kelengkapan dokumen permohonan kredit ditandatangani dan diserahkan ke bagian akuntansi.

7. Bagian akuntansi menerima kelengkapan dokumen permohonan kredit.

8. Berdasarkan dokumen-dokumen permohonan kredit, bagian akuntansi mengisi formulir calon anggota, mengisi formulir perjanjian kredit, mengisi formulir surat penyerahan dan kuasa menjual jaminan, mengisi tanda terima titipan dan pernyataan dan membuatkan kartu anggota , 1 untuk diarsipkan bersama dokumen-dokumen permohonan kredit dan 1 diserahkan ke bagian kasir.

9. Bagian kasir menerima kartu anggota serta membuat slip tanda menerima jaminan dan slip bukti penerimaan pinjaman masing-masing rangkap 2 lembar, 1 untuk diarsipkan dibagian kasir dan 1 diserahkan kepada pemohon kredit beserta uang dan kartu anggota. 
10. Pemohonn kredit menerima kartu anggota, slip tanda penerimaan jaminan dan slip bukti penerimaan pinjaman beserta uang. selanjutnya pemohon kredit memberikan BPKB kepada bagian akuntansi

11. Bagian akuntansi menerima BPKB yang selanjutnya mencatat data peminjam ke dalam buku daftar jaminan, buku register, buku SWP, dan buku rekapitulasi. Selesai.

Gambar 1

Bagan Alur Flowchart

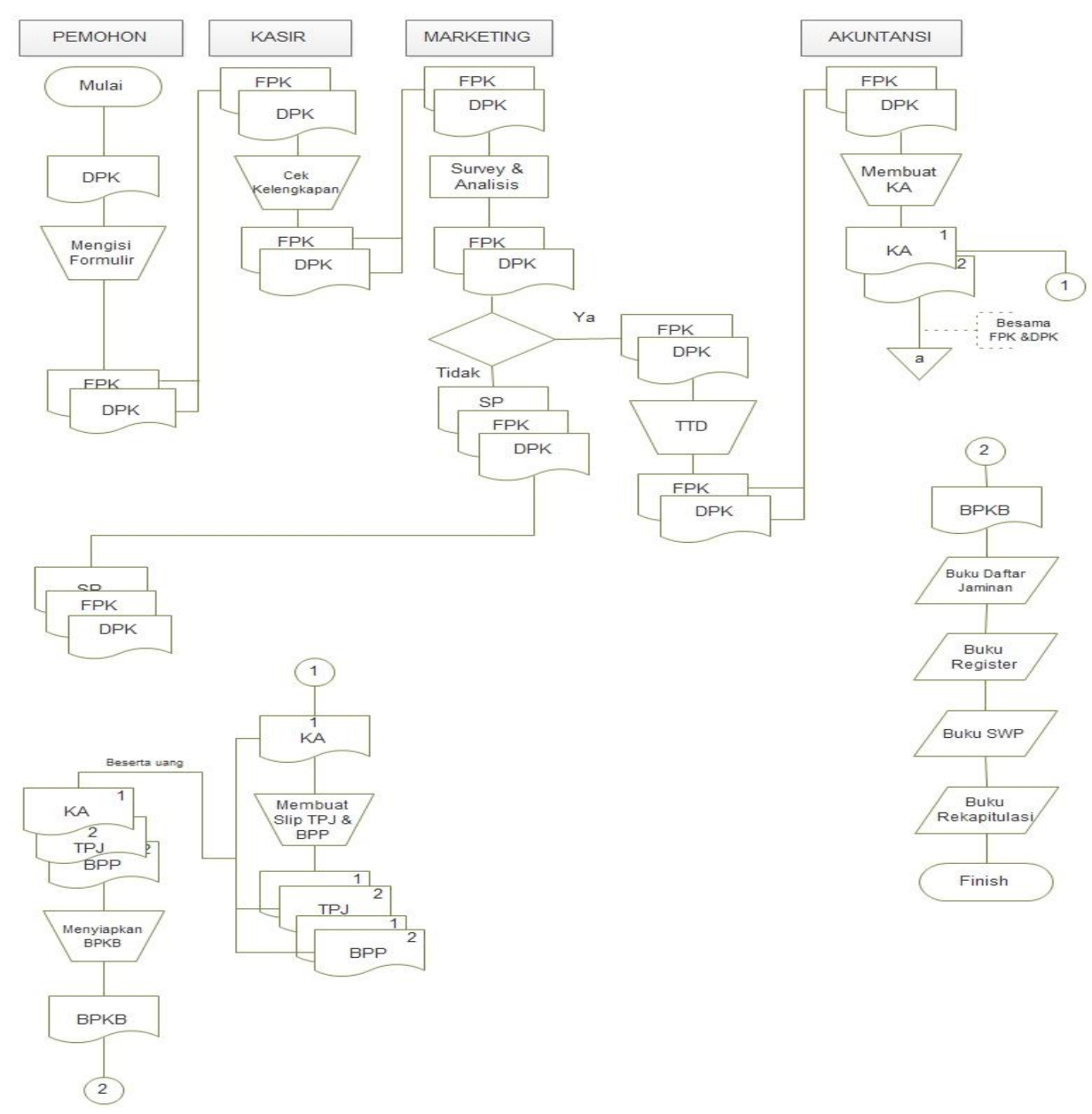

Keterangan:

DPK

FPK

SP

KA

TPJ

BPP

SWP

BPKB
: Dokumen Permohonan Kredit

: Formuler Permohonan Kredit

: Surat Pemberitahuan

: Kartu Anggota

: Tanda Penerimaan Jaminan

: Bukti Penerimaan Jaminan

: Simpanan Wajib Peminjam

: Bukti Kepemilikan Kendaraan Bermotor 
Bagan alir flowchart diatas menunjukkan adanya dokumen-dokumen yang digunakan sebagai syarat dalam permohonan kredit. Dokumen tersebut diantaranya yaitu dokumen permohonan kredit, formulir penggajuan kredit dan foto copy BPKB atau foto copy surat tanah. Dokumen ini diverivikasi melewati beberapa jaringan prosedur. Hal ini merupakan suatu upaya yang dilakukan oleh koperasi untuk mengurangi resiko kredit bermasalah. Dengaan adanya prosedurprosedur yang ada untuk melengkapi persyaratan pemberian kredit bisa meminimalisir resio adanya kredit macet (Pemi R H dan Yuliastuti R, 2014). Selain itu juga perlu dibuatkan dokumen hasil analisis dan survey tersendiri, agar lebih mudah dalam pengawasan dan bisa diketahui dengan jelas hal-hal yang telah dianalisis yang membuat suatu permohonan kredit disetujui.

Bagan alir flowchart diatas juga menunjukkan adanya fungsi yang menjalankan tugas kerja ganda, yaitu fungsi marketing, yang menjalankan tugas kerja sebagai pencari nasabah dan juga sebagai penyurvey atau analisa kredit. Hal ini kurang sesuai dengan unsur pokok pengendalian intern dimana struktur organisasi yang memisahkan tanggungjawab fungsional secara tegas. Fungsifungsi yang ada di Koperasi Simpan Pinjam Tunas Arta makmur disesuaikan dengan kebutuhan koperasi. Pemisahan tugas yang sederhana akan memicu praktek yang tidak sehat (Prabawanti, A M ,moch dzulkiron dan nengah, 2014). Hal ini berpeluang adanya manipulasi data dari hasil analisa kredit tersebut. Pemisahan fungsi tanggungjawab yang jelas dan tegas akan mencerminkan transaksi atau kegiatan yang sebenarnya yang dilaksanakan oleh fungsi dari koperasi.sehingga otoritas dari suatu dokumen dikendalikan oleh fungsi yang berwenang dan system otorisasi tersebut akan menjamin dihasilkannya dokumendokumen akuntansi yang dapat dipercaya.

\section{PENUTUP}

\section{Kesimpulan}

Sistem informasi akuntansi pemberian kredit yang diterapkan pada Koperasi Simpan Pinjam Tunas Arta masih sangat sederhana. Dilihat dari prosedur yang digunakan, terlihat tiga fungsi yang terkait dengan sistem pemberian kredit yaitu, fungsi kasir, fungsi marketing dan fungsi akuntansi. Dimana fungsi marketing merangkap tugas kerja selain mencari nasabah juga melaksanakan tugas kerja sebagai surveyor. Analisi dan survey dalam pelaksanaannya masih kurang maksimal. Analisis 5C khususnya Capacity dan Condition economy tidak sepenuhnya diterapkan. Sehingga pemberian kredit hanya berdasarkan kepercayaan dan tanpa melakukan pemeriksaan lapangan yang lebih intensif.Selain itu dokumen yang digunakan sebagai persyaratan dalam pengajuan kredit oleh pemohon kredit cukup mudah. Pemohon hanya perlu menyiapkan foto copy KTP, Foto Copy KK, foto copy STNK dan BPKP sebagai barang jaminan, maka pemohonan kredit akan segera di acc tanpa melalui survey yang panjang. Sehingga hal ini membuat calon nasabah mudah memahi dan menjadi daya tarik untuk melakukan pinjaman di Koperasi Simpan Pinjam Tunas Arta.

\section{Saran}


Sebaiknya struktur organisasi di Koperasi Simpan Pinjam Tunas Arta makmur memisahkan tanggung jawab fungsional secara tegas dan jelas serta menambah fungsi analisis kredit tersendiri. Hal ini untuk menjamin tidak adanya manipulasi data. Selain itu sebaiknya dokumen permohonan kredit dibuatkan untuk dokumen hasil analisis kredit tersendiri. Sehingga ha ini menjamin datadata dari nasabah dan dari hasil analisis kredit mencerminkan data yang sesungguhnya.

\section{DAFTAR PUSTAKA}

Baridwan, zaki. 2009. Sistem Akuntansi Penyusunan Prosedur dan Metode. Yogyakarta: BPAA YKPN

Bungin, Burhan. 2012. Metode Penelitian Kualitatif (Aktualisasi Metodologis ke Arah Ragam Varian Kotemporer). Jakarta: PT. Raja Grapindo Persada

Firdaus, Rachmat. 2001. Manajemen Dana Bank. Bandung : STIE INABA

Hadi, Rosalina P dan yuliastuti R. 2014. Sistem pengendalian Internal Kredit pada Bank Danamon Cabang Kembang Jepun Surabaya. Jurnal Ilmu Dan Riset Akuntansi Vol.3 N. 11

Hasibuan, Melayu SP. 2001. Dasar-dasar Perbankan. Jakarta : Bumi Aksara

Kasmir. 2002.Bank dan Lembaga Keuangan Lainnya. PT Raja Grafindo Persada. Jakarta

Krismiaji. 2002. Sistem Informasi Akuntansi. Yogyakarta: UPP AMP YKPN.

Moleong, lexy J. 2005. Metode Penelitian Kualitatif. Edisi Revisi. Bandung: PT. Remaja Rosdakarya.

Muldjono, Teguh Pudjo. 2007. Managemen Perkreditan Bagi Bank komersial. Yogyakarta. BPFE

Muljono, Djoko. 2012. Buku Pintar Strategi Bisnis “Koperasi Simpan Pinjam. Yogyakarta: ANDI

Mulyadi. 2005. Sistem Informasi Akuntansi.Jakarta: Salemba Empat.

Partomo, Titik Sartika. 2009. Ekonomi Kperasi. Boogor: Ghalia Indonesia.

Prabawanti, A M dkk. 2014. Analisis Sistem dan Prosedur Akuntansi Pemberian

Kredit Modal Kerja Dalam Upaya Peningkatan Pengendalian Internal"studi pada BPR PermataArtha Surya Surabay.jurnal administrasi dan bisnis. Vol.17 no.2

Satradipuera, komaruddin.2004. Strategi Managemen Bisnis Perbankan Konsep dan Implementasi untuk Bersaing. Bandung: Kappa Sigma.

Sudikin, Basrowi. 2002. Metode Penelitian Kualitatif Perspektif Mikro. Surabaya: Insan Cendikia.

Sugiyono. 2014. Metode penelitian Kuantitatif Kualitatif dan R\&D. bandung : Alfabeta

Sugiyono.2016. Metode Penelitian Kuantitatif, Kualitatif dan R\&D. Bandung: Alfabeta

Suhardjono. 2003. Managemen Perkreditn Usaha Kecil dan Menengah. Yogyakarta. UPP AMP YKPN

Undang-Undang Republik Indonesia Nomor 25 tahun 1992 Tentang perkoperasian 